NBER WORKING PAPER SERIES

\title{
RISK SHARING AND ASSET PRICES: \\ EVIDENCE FROM A NATURAL EXPERIMENT
}

\author{
Anusha Chari \\ Peter Blair Henry \\ Working Paper 8988 \\ http://www.nber.org/papers/w8988 \\ NATIONAL BUREAU OF ECONOMIC RESEARCH \\ 1050 Massachusetts Avenue \\ Cambridge, MA 02138 \\ June 2002
}

Henry gratefully acknowledges the financial support of an NSF CAREER award and the Stanford Institute of Economic Policy Research (SIEPR). This is a revised version of NBER WP 8265. We thank Geert Bekaert, and Campbell Harvey for extensive comments on previous versions of this paper. We also thank Michael Brennan, Steve Buser, Kalok Chan, Judy Chevalier, Eugene Fama, Harrison Hong, Michael Melvin, Rich Lyons, Lubos Pastor, Paul Romer and seminar participants at the AFA, Chicago, Kansas, Michigan, NBER, North Carolina, Ohio State, Stanford, Virginia, and WFA for comments. Any remaining errors are our own. The views expressed herein are those of the authors and not necessarily those of the National Bureau of Economic Research.

(C) 2002 by Anusha Chari and Peter Blair Henry. All rights reserved. Short sections of text, not to exceed two paragraphs, may be quoted without explicit permission provided that full credit, including $\mathbb{C}$ notice, is given to the source. 
Risk Sharing and Asset Prices: Evidence From a Natural Experiment Anusha Chari and Peter Blair Henry

NBER Working Paper No. 8988

June 2002

JEL No. F3, F4, G12

\begin{abstract}
When countries liberalize their stock markets, firms that become eligible for purchase by foreigners (investible), experience an average stock price revaluation of 10.4 percent. Since the covariance of the median investible firm's stock return with the local market is 30 times larger than its covariance with the world market, liberalization reduces the systematic risk associated with holding investible securities. Consistent with this fact: 1) the average effect of the reduction in systematic risk is 3.4 percentage points, or roughly one third of the total effect; and 2) variation in the firm-specific response is directly proportional to the firm-specific change in systematic risk. The statistical significance of this proportionality persists after controlling for changes in expected future profits and index inclusion criteria such as size and liquidity.
\end{abstract}

Anusha Chari

University of Michigan Business School

701 Tappan Street

Ann Arbor, MI 48109

achari@umich.edu
Peter Blair Henry

Stanford University

Graduate School of Business

Stanford, CA 94305-5015

and NBER

pbhenry@stanford.edu 


\section{Introduction}

A central tenet of asset pricing theory is that capital will be allocated in such a way that risk-adjusted returns are equalized across assets. The level of expected stock returns should vary cross-sectionally according to the level of firms' exposure to systematic risks. Implications for changes in expected returns follow directly from the theory in levels. Whenever there is a change in the level of systematic risk, stock prices should change in such a way that risk-adjusted returns are equalized once again.

This prediction is testable empirically. In recent years a number of countries have undertaken stock market liberalizations. A stock market liberalization is a decision by a country's government to allow foreigners to purchase shares in that country's stock market. Opening the stock market to foreign investors enables domestic agents in a small open economy to share risk with the rest of the world. Since liberalizations alter the set of non-diversifiable risks for the representative investor, stock prices should move in line with the change in systematic risk.

It is important to understand whether stock prices respond to changes in systematic risk, because stock prices provide public signals of real investment opportunities (Fischer and Merton, 1984; Morck, 2000; Stulz, 1999a; Tobin and Brainard, 1977; Summers, 1985). If liberalization decreases the riskiness of a firm, then, all else equal, its stock price should increase. This price increase signals to managers that they can increase shareholder welfare by investing in physical capital. On the other hand, if liberalizations are associated with stock price increases that are unrelated to changes in risk, then the optimal investment response is less clear (Blanchard, Rhee and Summers, 1993; Morck, Shleifer, and Vishny, 1990). Therefore, an empirical analysis of whether 
stock prices move in line with changes in systematic risk also provides a first step toward understanding whether physical investment is efficiently reallocated when barriers to capital movements are removed.

This paper focuses on an experiment in which the level of systematic risk changes unexpectedly and examines whether expected returns move in a direction that is consistent with the theory. Specifically, firm-level, cross-country data are used to evaluate whether the stock price revaluations that occur when emerging economies open their stock markets to foreign investors are driven by changes in risk. The capital asset pricing model (CAPM) predicts that two effects will drive the stock price revaluation of each publicly traded firm within a given country (Stulz, 1999a, b, c). The first effect is common to all firms: a fall in the risk-free rate as the country moves from financial autarky to financial integration with the rest of the world (Lucas, 1990). The second effect is specific to any given firm. The greater the covariance of a firm's stock return with the local market relative to the covariance of its returns with the world market, the larger the firm-specific component of that firm's stock price revaluation.

When countries liberalize their stock markets, some publicly listed firms become eligible for foreign ownership (investible firms), while others remain off limits (noninvestible firms). This investible/non-investible aspect of the data generates two testable implications of the theory. First, take two firms that are identical except that one is investible and the other is non-investible. Theory predicts that the revaluation effect for the investible firm should be more strongly related to its covariance structure of returns than in the case of the non-investible firm. Second, the fall in the risk-free rate effect is a common shock to all firms in the economy. Therefore, this effect should be the same 
across investible and non-investible firms. This second implication provides a further consistency check of the theory.

Panel data estimations show that the data are consistent with both of these predictions. The firm-specific revaluations of investible securities are significantly related to the difference in the covariance of their returns with the local and world markets. An investible firm, whose historical covariance with the local market exceeds that with the world market by 0.01 , will experience a firm-specific revaluation of 3.4 percent when the stock market is liberalized. In contrast, there is no firm-specific revaluation for non-investible firms. The estimations also confirm that the common shock is indeed the same for investible and non-investible firms, as predicted by the theory.

The use of firm-level data in this paper departs from studies that use aggregate data to document the stock market revaluation that occurs when emerging economies liberalize (Bekaert and Harvey, 2000; Henry, 2000a; Kim and Singal, 2000). The evidence in these papers suggests that liberalizations substantially reduce the cost of capital. However, these papers are silent about whether this reduction stems from increased risk sharing. In principle, the observed revaluations could be driven entirely by changes in the risk-free rate. The problem is that we observe only one aggregate stock price revaluation per country when stock market liberalizations occur. This means that analyses of aggregate data do not provide sufficient degrees of freedom to disentangle the contribution of changes in the risk-free rate from those of risk sharing. ${ }^{1}$ In contrast, firmlevel data provide more than sufficient degrees of freedom with which to disentangle the

\footnotetext{
${ }^{1}$ This is a specific example of the more general point made by Stulz (1995a). Tests based on stock market indices have limited power in assessing the importance of barriers to international investment.
} 
common shock from that of the risk-sharing effect, thereby enabling the data to speak to the issue of whether diversification drives the revaluation of domestic securities.

However, the results need to be interpreted with caution, because the natural experiment studied in this paper has some limitations. The decision to liberalize may be endogenous. Policy makers may choose to open up when the stock market is doing well. In aggregate studies, endogeneity may result in upward-biased estimates of the mean liberalization effect. With cross-country, firm-level data, this bias should be picked up by the country-specific fixed effects. However, if the bias also has a component that is correlated with the firm-specific covariance structure of returns, then the point estimates may overstate the magnitude of the portion of the total revaluation effect induced by risk sharing. On the other hand, the results may understate the full impact of liberalization on stock prices, because the revaluation is measured as the stock price change that occurs on the implementation date. Liberalizations may be anticipated by the market, and prices may have adjusted prior to that date.

Finally, stock price revaluations may be driven by changes in discount rates or expected future cash flows. Unexpected stock price changes are a reasonable proxy for changes in required rates of return only if earnings growth is unaltered by liberalization. However, liberalizations may affect expected future cash flows. If this is the case, then firms may experience stock price revaluations that are unrelated to discount rates. The analysis controls for expected future profitability by using firm-level data on the actual growth rate of real earnings per share following liberalizations. Studies that focus on aggregate data use variables such as GDP growth rates to proxy for expected future cash flows. In comparison, firm-level data on actual earnings growth outcomes would seem to 
provide a more direct, albeit imperfect, measure of future earnings prospects.

Despite these limitations, studying this liberalization experiment through the lens of the stock market has at least two advantages. First, there is ample evidence that an unbiased assessment of the effects of public information releases is incorporated into stock prices (Fama, 1976). In particular, stock prices in the subset of countries relevant for this paper respond to news of major economic policy reforms (Henry, 2000a, b). Second, the stock market evidence is useful for evaluating whether theories of risk sharing have any empirical relevance. For example, although the revaluation estimates are noisy, they are economically and statistically significant. This fact suggests that risk sharing may be of quantitative importance.

The rest of this paper proceeds as follows. Section 2 discusses the theoretical motivation and presents descriptive evidence. Section 3 describes the data. Section 4 outlines the empirical methodology and reports the results. Section 5 discusses the results, their relationship to previous studies on international risk sharing and potential implications for future work in asset pricing and macroeconomics.

\section{Theoretical Motivation and Descriptive Findings}

The analysis builds on Stulz (1999c). Assume a small country whose equity market is completely segmented from world equity markets. Investors are risk-averse and care only about the expected return of their investment and the variance of that return. Also assume that all investors have identical risk aversion. With this last assumption, the price of risk in the country is a constant, which we denote by $\gamma$. Since the country's investors care only about the expected return and volatility of their invested 
wealth and that country's capital market is segmented from the rest of the world, it follows that the capital asset pricing model (CAPM) holds for that country. This implies that the aggregate risk premium on the small country's equity market before stock market liberalization is $\left(R_{M}-r_{f}\right)=\sigma_{M}^{2} * \gamma$, where $R_{M}$ is the expected return on the market, $r_{f}$

is the risk-free rate, and $\sigma_{M}^{2}$ is the variance of the return on the small country's market portfolio. It follows that the risk premium for a given firm $i$ before liberalization is $\beta_{i M} \sigma_{M}^{2} \gamma$, where $\beta_{i M}$ is the beta coefficient of firm $i$ before liberalization. Therefore, we may write:

$$
E\left[R_{i}\right]=r_{f}+\beta_{i M} \sigma_{M}^{2} \gamma
$$

Where $E\left[R_{i}\right]$ is the required rate of return on firm $i$ 's stock.

\section{A. Complete Liberalization}

Now consider the impact on firm $i^{\prime} s$ required rate of return when the country opens its stock market to the rest of the world and also allows its residents to invest abroad. Assume also that the expected value and variance of the profits from domestic production activities are not affected by liberalization. To eliminate the impact of differences in risk aversion, also assume that all investors in the world have the same constant relative risk aversion.

As a country opens up its stock market to foreign investors and lets its residents invest abroad, the residents of the country no longer have to bear all of the risks associated with the economic activities of the country. After liberalization, the small country's equity market becomes part of the global equity market and expands the 
diversification opportunities for foreign investors. Since the country is small, adding that country to the world portfolio does not increase the risk premium on the world market portfolio.

Let us assume that the liberalization is symmetric in the sense that now domestic residents can also invest abroad for purposes of international diversification. With completely open capital markets, the capital asset pricing model holds for the global equity market, so that the risk premium on any risky asset depends on its beta coefficient with respect to the world market portfolio. Let $E\left[R_{i}^{*}\right]$ be the required rate of return on firm $i$ in the integrated capital market equilibrium. It follows that

$$
E\left[R_{i}^{*}\right]=r_{f}^{*}+\beta_{i W}\left(R_{W}-r_{f}^{*}\right)
$$

where $\beta_{i W}$ denotes firm $i$ 's beta with the world market, $R_{W}$ denotes the expected real rate of return on the world equity market portfolio and $r_{f}^{*}$ the world risk-free rate. The risk premium on the world market portfolio is $E\left[R_{W}\right]-r_{f}^{*}=\gamma \sigma_{W}^{2}$, where $\sigma_{W}^{2}$ is the variance of the return on the world portfolio. Therefore, the required rate of return on firm $i$ after liberalization is given by

$$
E\left[R_{i}^{*}\right]=r_{f}^{*}+\beta_{i W} \sigma_{W}^{2} \gamma
$$

The link between the liberalization-induced change in the required rate of return on firm $i$ and its diversification properties can now be made transparent by subtracting equation (3) from equation (1). Performing a few steps of algebra and using the definitions of local and world betas yields the following result:

$$
\Delta R_{i}=E\left[R_{i}\right]-E\left[R_{i}^{*}\right]=\left(r_{f}-r_{f}^{*}\right)+\gamma D I F C O V
$$


Where $\Delta R_{i}$ is the change in the required rate of return on impact and $\operatorname{DIFCOV}=\left[\operatorname{Cov}\left(R_{i}, R_{M}\right)-\operatorname{Cov}\left(R_{i}, R_{W}\right)\right] . \quad$ Equation (4) highlights the two channels through which liberalization affects firm-level required rates of return. The first effect, a change in the risk-free rate, is common to all firms. ${ }^{2}$ The second effect of liberalization is idiosyncratic to firm $i$ and depends on the quantity in brackets on the right-hand side of equation (4): the covariance of firm $i$ 's stock return with the local market minus the covariance of firm $i$ 's stock return with the world market.

\section{B. Partial Liberalization}

In practice, when countries liberalize, only some firms become eligible for foreign ownership. What drives the change in the required rate of return for the non-investible securities? The risk associated with holding a single non-investible security before liberalization depends on its covariance with the entire domestic market. The risk associated with holding a non-investible security after liberalization depends on its covariance with the portfolio of non-investible securities (Errunza and Losq, 1985). Therefore, the change in the required rate of return for the non-investible security will depend on the difference between the two covariances. Specifically, define the variable DIFCOV1 as DIFCOV $1=\left[\operatorname{Cov}\left(R_{i}, R_{M}\right)-\operatorname{Cov}\left(R_{i}, R_{N}\right)\right]$ where $R_{N}$ is the expected return on the portfolio of non-investible securities. All else equal, the repricing of the noninvestible securities should be positively correlated with DIFCOV1.

\footnotetext{
2 A priori, the impact of this common shock may be ambiguous. If countries are capital scarce in autarky, the average cost of capital may fall if the liberalization results in a net capital inflow. On the other hand, if countries have followed policies of financial repression and interest rates were kept artificially low, the average cost of capital may increase if the stock market liberalization is accompanied by domestic financial deregulation. See Henry (2000b) for a more detailed discussion of these issues.
} 


\section{C. Mapping Theory to Data: Descriptive Findings}

Under the assumption that firms' expected future cash flows are unaffected by liberalization, the unexpected response of firm $i^{\prime} s$ stock price to news of the liberalization will mirror the change in the required rate of return on firm $i$ 's stock. The stock price will increase if liberalization lowers the required rate of return, and conversely, the stock price will decrease if liberalization raises the required rate of return. Accordingly, the unexpected stock price response to liberalization can be used as a proxy measure for confronting the theory with data.

Specifically, equation (4) predicts that the revaluation will have an intercept effect and a slope effect. The intercept term should be the same across investible and noninvestible firms within a given country. However, in order to test the theory we pool the data from several countries. The intercept term in this pooled sample should be the same, only after controlling for country-fixed effects. Therefore, the intercept term should be ignored in the description of the raw data. Examination of the intercept is deferred until Section 4, which does control for country-fixed effects. Equation (4) also predicts that the revaluation should be an increasing function of DIFCOV for the investible firms. ${ }^{3}$

Figure 1 reveals that the stock price revaluation for investible firms is an increasing function of DIFCOV, as theory predicts. It plots the unexpected stock price change for investible firms on the $\mathrm{y}$-axis and DIFCOV on the $\mathrm{x}$-axis. The statistical relationship between the revaluation of investible firms and DIFCOV is given by the following equation (robust t-statistics in parentheses, R-Squared $=0.27, \mathrm{~N}=248$ ):

\footnotetext{
${ }^{3}$ Since the coefficient of relative risk aversion is assumed to be the same across countries, the slope coefficient is also implicitly the same and therefore does not require a country-specific adjustment.
} 


$$
\Delta \ln \left(\text { StockPrice }_{i j}^{\text {Investible }}[0]\right)=-0.05+9.20 * \text { DIFCOV }_{i j}
$$

where $\Delta \ln \left(\right.$ StockPrice $\left._{i j}^{\text {Investible }}[0]\right)$ is the liberalization-month stock price change for investible firm $i$ in country $j$.

Figure 2 presents the scatter plot for non-investible firms. The statistical relationship between the revaluation of non-investible firms and DIFCOV is given by the following equation (robust t-statistics in parentheses, R-Squared=0.06, N=181):

$$
\Delta \ln \left(\text { StockPrice }_{i j}^{\text {Non-Investible }}[0]\right)=0.053+3.69 * \text { DIFCOV }_{i j}
$$

Like Figure 1, this graph also reveals a positive statistical relationship between the revaluation of non-investible firms and DIFCOV.

However, there are also some distinct differences between Figure 1 and Figure 2. First, the positive relationship between the revaluation and DIFCOV is more pronounced for investible firms (Figure 1) than non-investible firms (Figure 2). The slope of the line in equation (5) is 9.20 whereas the slope of the line in equation (6) is 3.69. Second, the difference in covariance explains almost 30 percent of the cross-sectional variation in investible firms' stock price revaluations, but only 6 percent for non-investible firms. Thus, a first pass at the data indicates that DIFCOV has more predictive power for the revaluation of investible firms than non-investible firms.

Figure 3 examines whether the repricing of non-investible firms is related to the difference between their covariance with the local market portfolio and their covariances with the entire portfolio of non-investible securities. Figure 3 plots the unexpected stock price change for investible firms on the y-axis and DIFCOV1 on the $\mathrm{x}$-axis. The statistical relationship between the revaluation of non-investible firms and DIFCOV1 is 
given by the following equation (robust t-statistics in parentheses, R-Squared $=0.01$, $\mathrm{N}=181)$ :

$$
\Delta \ln \left(\text { StockPrice }_{i j}^{\text {Non-Investible }}[0]\right)=0.07+1.44 * \operatorname{DIFCOV1}_{i j}
$$

It appears that DIFCOV1 has no explanatory power for the repricing of non-investible securities.

This initial perusal of the data suggests that there are differences between investible and non-investible firms, but only so much can be inferred from pictures. Section 4 of the paper pools the data for both sets of firms and formally tests for differences between the two sets of firms. For that matter, both figures should be treated with caution because they merely plot the raw data. For example, the unexpected stock price change is a reasonable proxy for the change in required return if earnings growth is unchanged by liberalization. If this assumption is not reasonable, then it may be important to control for changes in the expected growth rate of earnings.

Additionally, there is a more general concern. The goal is to estimate the impact of liberalization on a randomly selected firm from the population of all firms. If the investible firms are not randomly selected, then they may have unobservable characteristics that cause them to respond differently to liberalization than non-investible firms. These issues can be explored more transparently once the data have been described in more detail. This data description takes place in the next section of the paper.

\section{Data}


This section of the paper discusses the data in some detail. The analysis requires three types of data: stock returns for the countries in question; stock market liberalization dates; a means of discriminating between those firms that become eligible for foreign ownership when the market is liberalized and those that do not. Section 3A describes the basic stock returns data. Section 3B gives the stock market liberalization dates. Section $3 \mathrm{C}$ explains the procedure for discriminating between investible and non-investible firms. Section 3D presents descriptive statistics on the two sets of firms. Section 3E discusses the potential importance of selection bias issues in examining investible versus noninvestible firms.

\section{A. The Basic Stock Returns Series}

The principal source of stock market data is the International Finance Corporation's (IFC) Emerging Markets Data Base (EMDB). ${ }^{4}$ Stock price indices for individual firms are the dividend-inclusive, U.S. dollar-denominated, IFC Global Index (IFCG). The IFC selects stocks for inclusion in the IFCG index by reviewing a stock's trading activity. Any share selected must be among the most actively traded shares in terms of value traded during the annual review period; it must have traded frequently during the review period (i.e., one large block trade might skew the value traded statistics); and it must have reasonable prospects for a continued trading presence in the stock exchange (e.g., it must not be in imminent danger of being suspended or delisted). Stocks are selected in order of trading criteria until the market capitalization coverage target of 60 percent to 75 percent of total market capitalization is met. Once the actively

\footnotetext{
${ }^{4}$ IFC data is used instead of Morgan Stanley Capital Index (MSCI) data, because MSCI company level coverage for emerging markets begins only in January 1992 and therefore post-dates almost all of the liberalizations. Worldscope coverage begins even later than MSCI coverage.
} 
traded and market capitalization requirements are met, IFC analysts may suggest substituting one company's shares for another on the list if the suggested shares have reasonably similar trading characteristics, but represent an industry group which may be underrepresented in the current composition of the IFCG index (IFC, 1999).

In order to be included in the sample, a firm must have been actively traded for at least five years prior to the liberalization date. This ensures that there are at least five years worth of data with which to calculate historical covariances. Each country's U.S. dollar-denominated total return index is deflated by the U.S. consumer price index (CPI), which comes from the IFS. All of the data are monthly. Returns are calculated as the first difference of the natural logarithm of the real stock total return index.

Calculation of the covariance of firm-level stock returns with the local and world markets requires data on market returns as well as firm-level returns. For each country, the real, dollar-denominated IFCG Total Return Index is used as the benchmark local market index. The world benchmark market index is the real, dollar-denominated MSCI World Total Return Index.

\section{B. Identifying Stock Market Liberalization Dates}

A stock market liberalization is a decision by a country's government to open its stock market to foreign investors. When a stock market liberalization occurs, some of the firms in the domestic economy become eligible for purchase by foreigners, while others remain off-limits. Establishing the liberalization date is the first step in the process of distinguishing between these two types of firms. These dates are listed in Table 1. The entire sample consists of 429 firms in 11 countries. The 11 countries are: Argentina, 
Brazil, Chile, Colombia, India, Korea, Mexico, Pakistan, Taiwan, Turkey, and Venezuela.

\section{C. Discriminating Between Investible and Non-Investible Firms}

Investible firms are defined to be that subset of firms in the IFCG that are also in the IFC Investible Index (IFCI). The IFCI's determination of investibility is a three-step process. First, the IFC determines which securities foreigners may legally hold. Next, the IFC applies two further screening criteria for practicality of investment. Both screens must be passed for IFCI index eligibility. The first criterion screens for a minimum investible market capitalization of $\$ 50$ million or more over the 12 months prior to a stock's addition to an IFCI index. This investible market capitalization is determined after applying the foreign investment rules and after any adjustments because of crossholdings or government ownership.

The second criterion screens firms for liquidity. A stock must trade at least $\$ 20$ million over the prior year for inclusion in an IFCI index. It must also have traded on at least half the local exchange's trading days. Thus, the IFC Investible indexes are designed to measure the returns that foreign portfolio investors might receive from investing in emerging market securities that are legally and practically available to them.

The IFCI was initiated in December of 1988. This fact implies that for stock market liberalizations that occurred prior to December of 1988 , it is not possible to discriminate between those firms that became investible and those that did not. The countries and dates in Table 1 reflect this constraint. Specifically, Table 1 lists the 
earliest stock liberalization date occurring after December of 1988 for every country that implemented at least one country-wide stock market liberalization after this date.

\section{D. Descriptive Statistics on Investible and Non-Investible Firms}

The average size of DIFCOV is 0.018 for investible firms and 0.0096 for noninvestible firms. This feature of the data suggests that investible firms should experience larger revaluations than non-investible firms, given the common shock. Table 2 explores whether the raw differences in the stock price revaluations of investible and noninvestible firms are roughly consistent with this prediction. The table shows that the average stock price revaluation is 15.1 percent in real dollar terms for investible firms and 9.9 percent for non-investible firms. The last column of the table reports that the 5.2 percentage-point difference between these two means is statistically significant. There are two possible concerns with these numbers.

First, they are reported in dollar terms. This choice of unit may lead to an overstatement of the revaluations if liberalizations are accompanied by large appreciations of the domestic currency vis-à-vis the dollar. In order to see if the dollardenominated revaluations are driven by domestic currency gains, the behavior of exchange rates in the sample countries was examined. On average, countries actually experience a 1.2 percent depreciation of their exchange rates during the liberalization month. The average depreciation during the month after liberalization is 1.5 percent. This suggests that the dollar-denominated numbers may actually understate the true size of the revaluation in local currency terms. Second, the numbers may understate the true 
revaluations if the liberalization events are anticipated. ${ }^{5}$ Analysis of returns during the months preceding the liberalization revealed no evidence of significant stock price appreciation in anticipation of the liberalizations.

Turning to comparisons of medians, the median revaluation for investible firms is 12.1 percent. Forty-three of the 248 investible firms in the sample had liberalizationmonth stock price changes below their median monthly stock price change. The p-value is 0.00 for observing at most this many investible firms with liberalization-month stock price responses below their median monthly stock price change for non-liberalization months. ${ }^{6}$ The median revaluation for non-investible firms is 8.6 percent. Eighty-three of the 181 non-investible firms experienced liberalization-month stock price changes below their median monthly stock price change. The p-value is 0.15 for observing at most this many stock price responses below the median. Hence, sign tests confirm that the stock price revaluations for investible firms are more uniformly positive than for non-investible firms.

\section{E. Is There a Sample Selection Problem?}

Those firms that become investible may not represent a random sampling from the distribution of all firms in the IFCG, which are themselves not randomly selected. To explore whether selection bias may prejudice the results, this section systematically examines the structural differences between investible and non-investible firms.

Table 3 provides a comparison of ex-ante observable differences in investible and non-investible firms, as a second step in exploring the extent to which selection bias may

\footnotetext{
${ }^{5}$ If the news is anticipated, this biases against finding any revaluation effect.

${ }^{6}$ The null hypothesis is that liberalization-month stock price responses come from the same distribution as non-liberalization-month stock price changes.
} 
prejudice inferences about the differential impact of liberalization on the two sets of firms. Summary statistics on six variables are provided for investible and non-investible firms in the pre-liberalization period: SIZE, market capitalization as a fraction of total market capitalization; LIQUIDITY, the turnover rate; EARNINGS, the growth rate of real earnings per share; MARKET TO BOOK, the ratio of the market value of equity to the book value of equity; RETURN, the average real return in dollars; and DIFCOV, the difference in covariance between the local and world markets. There is no significant difference between the size of investible and non-investible firms. Investible firms are significantly more liquid than non-investible firms.

The average growth rate of real earnings per share for investible firms is significantly higher than that of non-investible firms. Investible firms also have significantly higher market-to-book ratios than non-investible firms. This may indicate that investible firms have higher expected future profitability than non-investible firms. If higher market to book ratios and historical growth rates of real earnings per share rationally forecast that investible firms have higher expected profitability than noninvestible firms, then we should see differences in ex-post earnings growth outcomes, on average.

Hence, Table 4 reports a comparison of the actual growth rate of real earnings per share for investible and non-investible firms in each of the three years following liberalization $([+1],[+2],[+3])$, as a further means of exploring selection bias. In the second and third years after liberalization, there are no significant differences. In the year after liberalization, the growth rate of earnings per share for non-investible firms is significantly lower than for investible firms. Although there are no dramatic differences 
in ex-post profitability of investible and non-investible firms, overall the data do suggest that there are some differences between these two types of firms. The empirical analysis in Section 4 controls directly for the influence of earnings on the revaluations, so some of these differences will be accounted for. However, it is possible that these differences could be correlated with characteristics that influence the way in which investible and non-investible stock prices respond to liberalization.

Another possible concern is the process by which firms become legally investible. If decisions concerning the permissibility of foreign ownership are made at the country level (by government officials), then stock market liberalization may be an exogenous event from the perspective of any given firm. On the other hand, if legal investibility is determined on a firm-by-firm basis, then sample selection may be an issue. For example, if a firm must lobby the government to allow foreign institutions to buy its shares, then those firms that are most attractive to foreigners will be most likely to engage in the lobbying process. This discussion suggests that those firms that are "investible" may not represent a random sampling from the distribution of all firms in the IFCG.

The extent to which liberalization may be regarded as exogenous was investigated. The variation in the "degree open factor" across firms for each country was examined. For 10 of the 11 countries in the sample, the degree open factor was identical across all firms at the time of the stock market liberalization. ${ }^{7}$ The uniformity of the degree of openness across firms within a given country suggests that either the liberalization decision is exogenous to any given firm, or all firms within a given country uniformly prefer the same degree of permissible foreign ownership. However, the government's decision about which firms to make investible may be a function of firm-

\footnotetext{
${ }^{7}$ The exception is Brazil where the investible weights range from 5 percent to 56 percent across firms.
} 
specific characteristics that determine the likely impact of liberalization on that firm, even if the liberalization decision is exogenous from the firm's perspective.

\section{Methodology and Empirical Results}

This section of the paper addresses the following question. Do diversification fundamentals help predict the unexpected stock price change in response to the news of stock market liberalization? The benchmark regression specification is as follows:

$$
\begin{aligned}
& \Delta \ln \left(\text { StockPrice }_{i j}[0]\right)=\alpha+\beta_{1} \text { INVEST }_{i j}+\gamma_{1} \text { DIFCOV }_{i j}+\gamma_{2}\left(\text { DIFCOV }^{*} I N V E S T\right)_{i j} \\
& + \text { CNTRY }_{j}+\varepsilon_{i j}
\end{aligned}
$$

The left-hand-side variable is the Month " 0 " unexpected stock price change. Month 0 is defined as the month in which a given stock market liberalization is implemented. The IFC records the value of a country's stock market index at the end of the month, and the data on liberalization events do not provide the day of the month on which programs are implemented. These two facts imply that the implementation of a given liberalization may occur after the day of the month on which the IFC recorded prices. In such cases, the change in the stock market index in month [0] may not reflect the news of the liberalization event. Accordingly, the analysis looks at the cumulative unexpected change in the real dollar value of the stock market index in months $[0,+1]$ as well as the change in month [0].

The unexpected stock price change for a given firm, $i$, is computed as the real dollar return for firm $i$ in the liberalization month minus firm $i$ 's average, preliberalization, monthly return. The symbol DIFCOV is an abbreviation for $\left[\operatorname{Cov}\left(R_{i}, R_{M}\right)-\operatorname{Cov}\left(R_{i}, R_{W}\right)\right]$, the difference between the historical covariance of firm $i$ 's 
stock return with the local market and its covariance with the MSCI world stock market index. INVEST is a dummy variable that takes on a value of one for investible firms and zero for non-investible firms. CNTRY is a set of country specific dummies to account for country-fixed effects.

This specification facilitates examination of the revaluation effect for a pooled group of 429 investible and non-investible firms. The joint estimation procedure allows testing of the view that risk sharing drives the stock price revaluations that accompany stock market liberalizations for both investible and non-investible firms. The constant intercept term, $\alpha$, imposes the assumption that the change in the risk-free rate is the same across all countries, after controlling for country-fixed effects. If the theory is correct, $\alpha$, the average change in the risk-free rate after removing country-fixed effects, should be the same for investible and non-investible firms. The coefficient on the dummy variable INVEST measures the marginal effect on $\alpha$ of being investible. If the theory is correct, the coefficient on INVEST should not be significantly different from zero.

In principle, estimating equation (8) without country-fixed effects would yield an estimate of the average change in the risk-free rate across all 11 countries. In practice, an estimate of $\alpha$ without fixed effects could pick up other level effects related to countryspecific differences that are not addressed by the theory. Without a clear framework for interpreting such differences, it seems preferable not to try and interpret the country-fixed effects as country-specific changes in the risk-free rate. Rather, the empirical analysis simply asks whether the common shock is the same across all firms after controlling for country-fixed effects. 
The usual assumption that the error term is random and uncorrelated across firms requires further discussion. Equation (8) is estimated using a panel regression with country-fixed effects. In aggregating abnormal returns, the standard assumption for panel estimation requires that the abnormal returns on individual securities be uncorrelated in the cross section. This is a reasonable assumption if there is no clustering, that is, the event windows of the included securities do not overlap in calendar time. However, this is not true for country-wide stock market liberalizations. All firms within a given country share the same liberalization date in addition to other country-specific factors. Therefore, the standard assumption that abnormal returns are uncorrelated across firms may no longer obtain. This means that the standard distributional results for the aggregated abnormal returns may not be applicable in this context. The variance-covariance matrix used to calculate the standard errors was adjusted to account for clustering. The estimation procedure also corrects for potential heteroscedasticity across firms.

\section{A. Benchmark Regression Results}

Table 5 shows the results. Panel A presents the estimates for the month [0] windows. Column (1a) shows the results for the benchmark specification given by equation (8). The estimate of the constant captures the common shock for both the investible and the non-investible firms. The magnitude of this coefficient is 0.06 and is significant at the 1 percent confidence level. The INVEST dummy is statistically insignificant. This indicates that the common shock is in fact the same for both sets of firms, as theory would predict. 
The intercept term was also estimated without country-fixed effects. In this case, the point estimates ranged from -0.01 to 0.03 , but were statistically insignificant in all specifications. The standard errors on the point estimates without fixed effects were on the order of 0.3 , as opposed to standard errors on the order of 0.01 with fixed effects. These numbers suggest that there is a great deal of variation in the common shock from country to country. This could be due to large differences in domestic and world riskfree rates, but it could also be due to other country-specific effects. Henceforth the analysis only discusses the estimates that include fixed effects.

The coefficient on DIFCOV gives the effect of risk sharing conditional on being non-investible. The sum of the coefficients on DIFCOV and DIFCOV*INVEST gives the total effect of risk sharing conditional on being investible. The sum of the coefficients on DIFCOV and DIFCOV*INVEST in this benchmark specification is equal to 2.74 and is significant at the one percent confidence level. This means that if DIFCOV equals 0.01 , then an investible firm can expect a stock price revaluation of 0.274 or 2.74 percent in the month that the stock market liberalization takes place. Panel B presents the estimates for the month $[0,+1]$ window. Column (1b) shows that the conditional effect of DIFCOV for non-investible firms is equal to -0.4 and is statistically insignificant. The conditional effect for investible firms is equal to the sum of -0.4 and 4.42 , which is 4.02 . Therefore, if DIFCOV equals 0.01, a firm can expect a total stock price revaluation of 4.02 percent over the two-month window.

It is also important to note that the marginal effect of DIFCOV conditional on being an investible firm is captured by the coefficient on DIFCOV*INVEST. Therefore, the point estimates in the benchmark specifications (1a and 1b) also indicate that the 
marginal effect of DIFCOV for investible firms is significantly different from that of the non-investible firms. Overall, the empirical results from the benchmark specifications are consistent with the a priori theoretical predictions. The stock price revaluation of investible firms is positively and significantly related to DIFCOV. There is no significant statistical relationship between the stock price revaluation of non-investible firms and diversification fundamentals. The finding for non-investible firms is consistent with the prediction in the case where the stock market liberalization does not allow domestic residents to invest abroad.

\section{B. Controlling for Earnings Growth}

Stock price revaluations may be driven by changes in earnings or discount rates. If liberalization coincides with good news about earnings, then firms may experience stock price revaluations that are unrelated to liberalization-induced changes in the discount rate. Specifications (2a) and (2b) of Table 5 explore whether the differences in the effect of DIFCOV on the stock price revaluation of investible and non-investible firms reported in specifications (1a) and (1b) are driven by shocks to the growth rate of earnings. The deviation of the growth rate of earnings from its pre-liberalization mean in year $[+1]$ is added to the right-hand side of equation (8) as a proxy for changes in expected future profitability. ${ }^{8}$

After controlling for earnings in Panel A, the sum of the coefficients on DIFCOV and DIFCOV*INVEST increases to 3.3 in column (2a). This is up from the estimate of 2.74 in the benchmark specification (1a). After controlling for earnings in Panel B, the sum of the coefficients on DIFCOV and DIFCOV*INVEST increases to 4.5 in

\footnotetext{
${ }^{8}$ Estimations were also performed using years $[0],[+1],[+2]$, and $[+3]$. These results are not reported because earnings in $[0],[+2]$, and $[+3]$ have no explanatory power.
} 
specification (2b). This is greater than the estimate of 4.02 in the benchmark specification (1b). The point estimate on DIFCOV, the risk-sharing effect for noninvestible firms, remains statistically insignificant in both Panel A and Panel B. The coefficient on DIFCOV*INVEST in (2a) and (2b) indicate that the marginal effect of DIFCOV for investible firms remains significantly larger than that of the non-investible firms.

\section{C. Can Size or Liquidity Explain the Results?}

Regulatory guidelines within asset management companies often restrict portfolio managers to holding stocks that are included in investible indices such as IFCI. In order to be included in the IFCI, firms must pass minimum size and liquidity screens, in addition to being legally investible. It is possible that the results thus far overstate the effects of diversification because DIFCOV proxies for omitted structural characteristics such as size and liquidity that are important practical determinants of asset demands.

In order to account for the potential impact that size and liquidity considerations may have on the results, this subsection adds size and turnover measures to the right-hand side of equation (8). The following regression examines the effect of DIFCOV on revaluation after controlling for size:

$$
\begin{aligned}
& \Delta \ln \left(\text { StockPrice }_{i j}[0]\right)=\alpha+\beta_{1} \text { Invest }_{i j}+\gamma_{1} \text { DIFCOV }_{i j}+\gamma_{2}\left(\text { DIFCOV }^{*} I N V E S T\right)_{i j} \\
& +\gamma_{3} \text { Earn }_{i j}+\gamma_{4}\left(\text { SIZE }^{*} I N V E S T\right)_{i j}+\gamma_{5}\left(\text { SIZE }^{*} \text { NONINVEST }\right)_{i j}+C N T R Y_{j}+\varepsilon_{i j}
\end{aligned}
$$

For a given firm, SIZE is defined as the ratio of that firm's market capitalization to the total domestic market capitalization as of one year prior to the liberalization date.

Specification (3a) reports the results. The revaluation for investible firms remains positively and significantly related to DIFCOV after controlling for SIZE. In Panel A, the point estimate of DIFCOV is 3.47 and significant at the 1 percent level. After 
controlling for SIZE in Panel B, the point estimate of DIFCOV is 4.64 and significant at the 1 percent level. In both Panels A and B, the conditional effect of DIFCOV for investible firms remains statistically insignificant. The coefficient on DIFCOV*INVEST indicates that the marginal effect of DIFCOV for investible firms continues to be significantly larger than that of the non-investible firms. The coefficient on the SIZE variable is not significant in any of the specifications

The following regression explores whether the positive relationship between the unexpected stock price change and the change in covariance persists after controlling for liquidity, as measured by turnover:

$$
\begin{aligned}
& \Delta \ln \left(\text { StockPrice }_{i j}[0]\right)=\alpha+\beta_{1} \text { Invest }_{i j}+\gamma_{1} \text { DIFCOV }_{i j}+\gamma_{2}\left(\text { DIFCOV }^{*} \text { INVEST }_{i j}\right. \\
& +\gamma_{3} \text { Earn }_{i j}+\gamma_{4}\left(\text { TURNOVER }^{*} \text { INVEST }_{i j}+\gamma_{5}\left(\text { TURNOVER }^{*} \text { NONINVEST }\right)_{i j}+\right. \\
& \text { CNTRY }_{i j}+\varepsilon_{i j}
\end{aligned}
$$

For a given firm, the variable TURNOVER is defined as the sum of the dollar value of all shares traded over a 12-month period before the liberalization $(t=-24$ to $t=-12)$ divided by that firm's total market capitalization. The total market capitalization number for the firm is taken at $t=-12$.

Regression (4a) in Panel A of Table 5 shows that after controlling for the effect of liquidity on the stock price revaluation for investible firms, the sum of the coefficients on DIFCOV and DIFCOV*INVEST is 3.25 and significant at the 1 percent level. Regression (4b) in Panel B of Table 5 shows that the sum of the coefficients on DIFCOV and DIFCOV*INVEST is 4.44 and significant at the 1 percent level. In both Panels A and $\mathrm{B}$, the conditional effect of DIFCOV for investible firms remains statistically insignificant. The coefficient on DIFCOV*INVEST indicates that the marginal effect of DIFCOV for investible firms continues to be significantly larger than that of the non- 
investible firms. The variable TURNOVER is statistically insignificant for the investible firms and enters negatively and significantly for the non-investible firms.

\section{D. Summary}

On balance, the evidence suggests that risk sharing helps explain the revaluation effect for investible firms only. The marginal effect of DIFCOV for investible firms is significantly larger than that of the non-investible firms in all specifications. The hypothesis that the impact of DIFCOV on the stock price revaluation is the same for investible and non-investible firms is rejected in the benchmark specification as well as those that include controls for earnings, size, and liquidity. The common shock, as measured by the coefficient on the constant term, is positive and significant in all specifications. Importantly, the marginal effect of INVEST on the constant term is statistically insignificant in all specifications. This means that the intercept term is in fact the same for investible and non-investible firms. This second piece of evidence provides further confirming evidence in support of the theory.

It is useful to check the plausibility of the results by performing some crude calculations and comparing them to the raw data. For investible firms, the sample average of DIFCOV is 0.018 . Multiplying this number by 2.74 (the estimate from Panel A (Column 1) in Table 5) gives 0.049, the total effect of DIFCOV for investible firms. Adding 0.049 to the coefficient on the constant, which is 0.06 , yields 0.109 . Thus, the total predicted revaluation for the investible firms is 10.9 percent in real dollar terms. The average revaluation in the raw data for investible firms is equal to 15 percent. The analogous calculation for the non-investible firms yields a predicted revaluation of 6.3 
percent. The average revaluation in the raw data for non-investible firms is equal to 9.9 percent.

\section{Discussion}

Typical analyses of the gains from international trade in risky assets calibrate the hypothetical welfare losses associated with the lack of risk sharing (French and Poterba, 1991; Lewis, 1999; Tesar, 1995; Tesar and Werner, 1998;). This paper takes a different approach. It analyzes the revaluation of the prices of publicly traded shares that actually occurs when emerging economies open their stock markets to foreign investors. Strictly speaking, stock price revaluations measure the change in real wealth that accrues to domestic shareholders, not utility gains per se. Nevertheless, stock market liberalizations provide useful natural experiments, because changes in real equity prices have implications for other macroeconomic variables that have broader welfare implications (Frankel, 1994; Henry 2000b; Stulz 1999a; Tesar and Werner, 1998).

Asset pricing theory predicts that levels of expected stock returns should vary cross-sectionally according to the level of firms' exposure to systematic risks. Research in the last several years has produced little empirical evidence in support of this claim (for surveys see Campbell, 2000; Cochrane, 1999; Fama, 1991). Systematic risk factors show little indication that they are priced cross-sectionally. Many firm characteristics that are priced cross-sectionally do not resemble systematic risk. Much of the research in this area has focused on the predictive ability of the CAPM for levels of systematic risk and expected returns. This paper focuses on an experiment in which the level of 
systematic risk changes and demonstrates that expected returns move in a direction that is consistent with the theory.

It is important to understand whether stock prices respond to changes in risk, because stock prices provide public signals of real investment opportunities. If liberalization leads to a fall in the riskiness of a firm, then, all else equal, its stock price should increase. In theory, the jump in stock prices that occurs at liberalization is the most direct signal that the policy change has reduced the cost of capital. All else equal, the optimal response to a fall in the cost of capital is to increase investment. On the other hand, if the stock price increases associated with liberalization are unrelated to diversification, then the optimal investment response is less clear (Blanchard, Rhee and Summers, 1993; Morck, Shleifer, and Vishny, 1990; Wurgler, 2000).

Morck et al. (2000) document evidence that stock prices in emerging economies contain relatively little firm-specific information. This conclusion may be right in general. However, this paper suggests that emerging market stock prices do convey information about firm-specific changes in risk when the economy is opened to foreign portfolio investment. More generally, the result that stock prices move in line with changes in systematic risk provides a first step toward understanding whether physical capital is efficiently reallocated when barriers to capital movements are removed. 


\section{References}

Adler, Michael and Bernard Dumas. (1983). "International Portfolio Choice and Corporate Finance: A Synthesis," Journal of Finance, Vol. 38, No. 3, pp. 925-84.

Bekaert, Geert and Harvey, Campbell. (2000). "Foreign Speculators and Emerging Equity Markets," Journal of Finance, Vol. 55, No. 2, pp. 565-613.

Blanchard, Olivier J., Rhee, C., and Lawrence Summers (1993). "The Stock Market, Profit, and Investment" Quarterly Journal of Economics, Vol. 108, pp. 115-36

Campbell, John Y. (2000). "Asset Pricing at the Millenium" Journal of Finance, Vol. 55, No. 4, pp. 1515-1567.

Cochrane, John. (1999). “New Facts in Finance" Economic Perspectives Federal Reserve Bank of Chicago, Vol. 23, No. 3, pp. 36-58.

Cutler, David, James Poterba, and Lawrence Summers. (1989). "What Moves Stock Prices?" Journal of Portfolio Management, Vol. 15, pp. 4-12

Errunza, Vihang and Etienne Losq. (1985). "International Asset Pricing under Mild Segmentation: Theory and Test," Journal of Finance, Vol. 40, No. 1, pp. 105-24.

Fama, Eugene F. (1976). Foundations of Finance. New York: Basic Books.

Fama, Eugene F. (1991). "Efficient Capital Markets: II," Journal of Finance, Vol. 46, No. 5, pp.1575-1617

Fischer, Stanley and Robert C. Merton. (1984). "Macroeconomics and Finance: The Role of the Stock Market," Carnegie-Rochester Conference Series on Public Policy, Vol. 21, pp. 57-108.

Frankel, Jeffrey (1994). "Introduction" in The Internationalization of Equity Markets. Jeffrey A. Frankel, ed. Chicago and London: University of Chicago Press, pp. 231-71.

French, Kenneth R. and James M. Poterba. (1991). "International Diversification and International Equity Markets," American Economic Review, Vol. 81, No. 2, pp. 222-26.

Henry, Peter Blair. (2000a). "Stock Market Liberalization, Economic Reform, and Emerging Market Equity Prices," Journal of Finance, Vol. 55, No. 2, pp. 529-64.

Henry, Peter Blair. (2000b). "Do Stock Market Liberalizations Cause Investment Booms?" Journal of Financial Economics, Vol. 58, Nos. 1-2, pp. 301-334. 
International Finance Corporation. (1999). The IFC Indexes: Methodology, Definitions, and Practices. Washington, D.C.

Kim, Han E. and Vijay Singal. (2000). "Stock Market Openings: Experience of Emerging Economies," Journal of Business, Vol. 73, No. 1, pp. 25-66.

Lewis, Karen K. (2000). "Why Do Stocks and Consumption Imply Such Different Gains from International Risk Sharing?" Journal of International Economics, Vol. 52, pp. 1-35.

Lewis, Karen K. (1999). "Trying to Explain Home Bias in Equities and Consumption," Journal of Economic Literature, pp. 571-608.

Lucas, Robert E. Jr. (1990). "Why Doesn't Capital Flow from Rich to Poor Countries?" The American Economic Review, Vol. 80, No. 2, pp. 92-96.

Morck, Randall, Bernard Yeung, and Wayne Yu. (2000). "The Information Content of Stock Markets: Why Do Emerging Markets Have Synchronous Stock Price Movements?" Journal of Financial Economics, Vol. 58, pp. 215-260

Morck, Randall, Andrei Shleifer, and Robert Vishny (1990). "The Stock Market and Investment: Is the Market a Sideshow?" Brookings Papers on Economic Activity, pp. 157-215.

Obstfeld, Maurice. (1994). "Risk-Taking, Global Diversification and Growth," American Economic Review, Vol. 84, No. 5, pp. 1310-29.

Obstfeld, Maurice and Kenneth Rogoff. (1996). Foundations of International Macroeconomics, Ch. 5, pp. 269-347, Cambridge and London, MIT Press.

Stulz, Rene M. (1995a). "International asset pricing: An integrative survey," Handbook of Modern Finance, R. Jarrow, M. Maximovich and W. Ziemba, eds. North Holland-Elsevier, pp. 201-223.

Stulz, Rene M. (1995b). "Globalization of Capital Markets and the Cost of Capital:The Case of Nestlé," Journal of Applied Corporate Finance, pp. 30-39.

Stulz, René M. (1999a). "International Portfolio Flows and Security Markets" in Martin Feldstein, ed. International Capital Flows. Chicago: University of Chicago Press.

Stulz, René M. (1999b). "Globalization, Corporate Finance, and the Cost of Capital" Journal of Applied Corporate Finance, vol. 12, pp. 8-25.

Stulz, Rene M. (1999c). "Globalization of Equity Markets and the Cost of Capital," Working Paper, Dice Center, Ohio State University. 
Stulz, René M., Bong-Chan Kho, and Dong Lee. (2000). "U.S. Banks, Crises, and Bailouts: From Mexico to LTCM" American Economic Review, Vol. 90, No.2, pp.28-31

Summers, Lawrence H. (1985). "On Economics and Finance" Journal of Finance, Vol. 40, No. 3, 633-635.

Tesar, Linda. (1995). "Evaluating the Gains from International Risk Sharing," Carnegie Rochester Conference Series on Public Policy, Vol. 42, pp. 95-143.

Tesar, Linda L. and Ingrid Werner (1995). "U.S. Equity Investment in Emerging Stock Markets," The World Bank Economic Review, Vol. 9, pp. 109-129.

Tesar, Linda L. (1999). "The Role of Equity in International Capital Flows" in Martin Feldstein, ed. International Capital Flows. Chicago: University of Chicago Press. pp. 235-55.

Tesar, Linda L., and Ingrid M. Werner. (1998). "The Internationalization of Securities Markets Since the 1987 Crash" in Robert E. Litan and Anthony M. Santomero eds.: Brookings -Wharton Papers on Financial Services (Brookings Institution Press, Washington)

Tobin, James and William C. Brainard. (1977). "Asset Markets and the Cost of Capital" in Balassa, B. and Nelson, R. (Eds.), Economic Progress, Private Values, and Public Policy. North Holland, Amsterdam, pp. 235-62.

Wurgler, Jeffrey (2000). "Financial Markets and the Allocation of Capital," Journal of Financial Economics, Vol. 58, pp. 187-214 
Figure 1. Differences Between Covariances with the Market and World Portfolio Help Explain the Repricing of Investible Firms

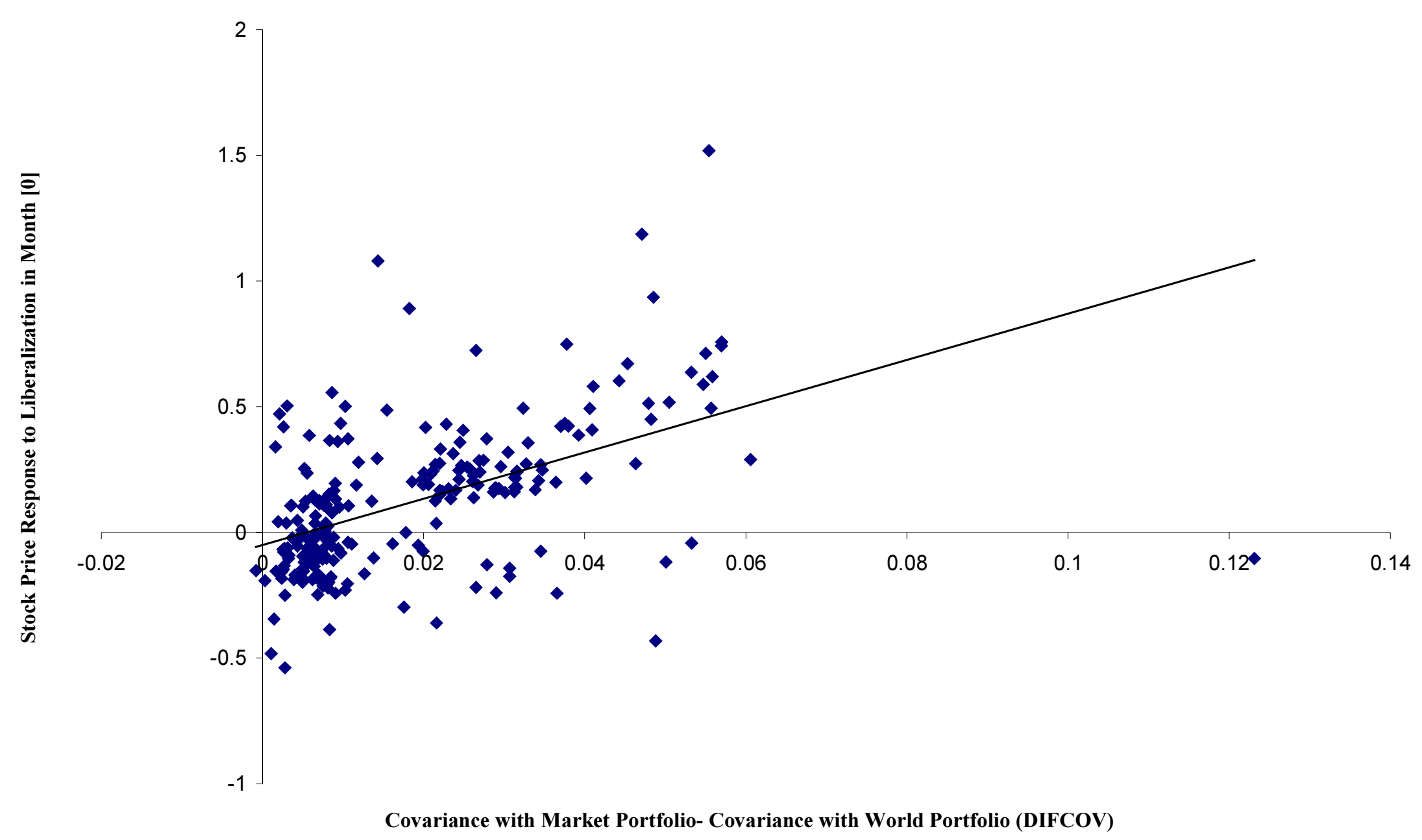


Figure 2. Differences Between Covariances with the Market and World Portfolio Do Not Help Explain the Repricing of Non-Investible Firms

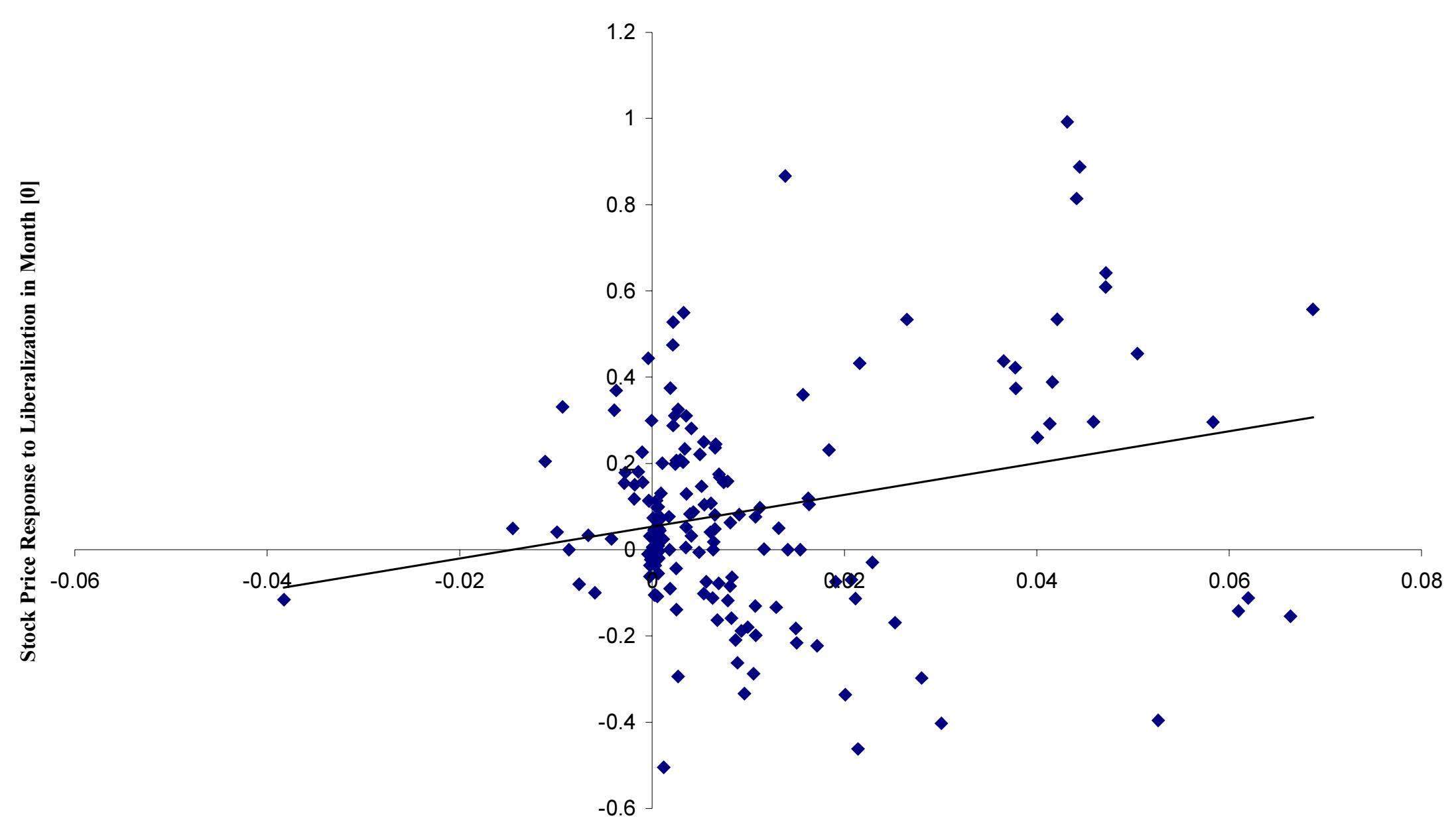

Covariance with Market Portfolio- Covariance with World Portfolio (DIFCOV) 
Figure 3. Differences Between Covariances with the Market and Non-Investible Portfolio Do Not Help Explain the Repricing of Non-Investible Securities

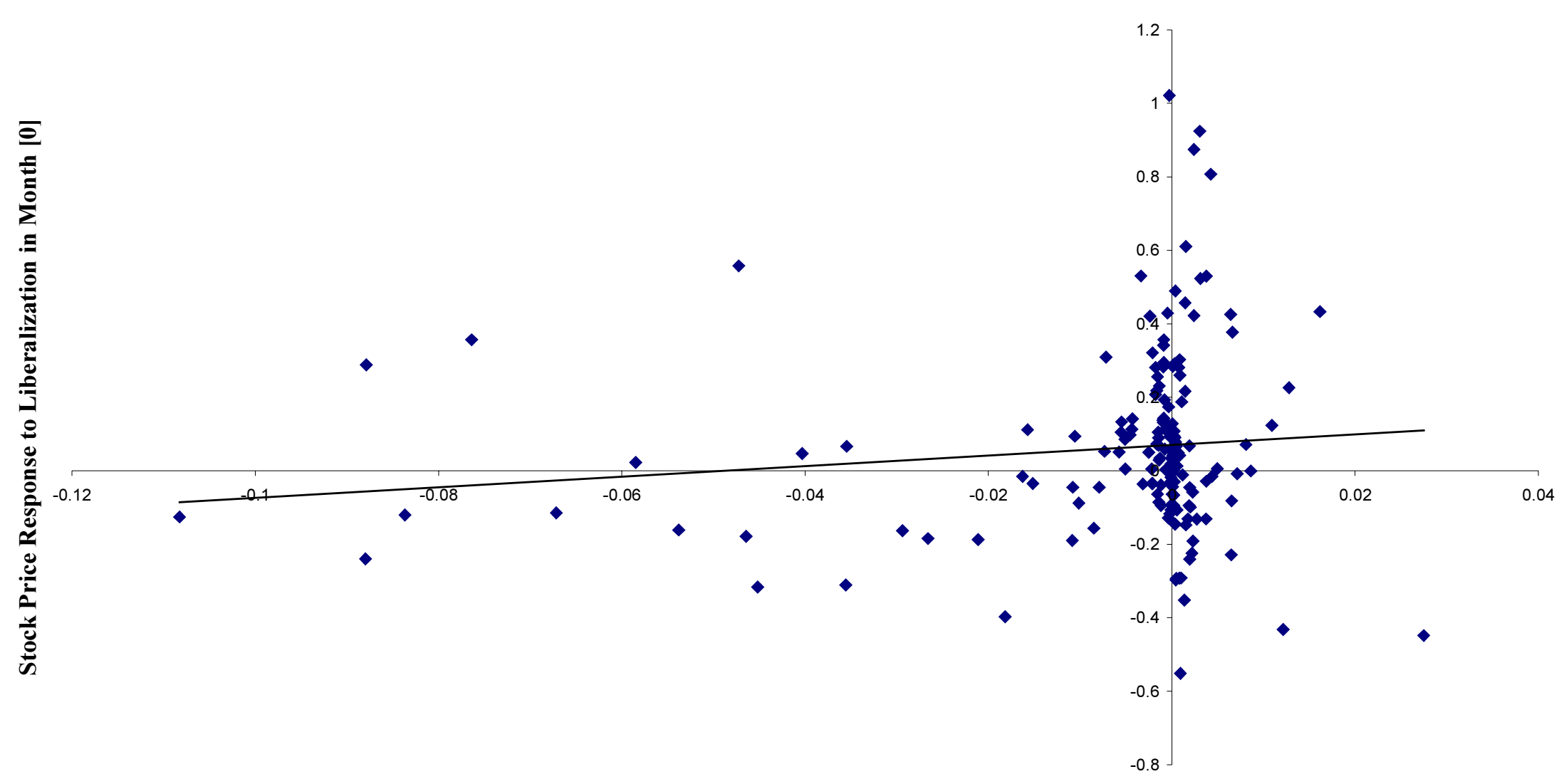

Covariance with Market Portfolio - Covariance with Non-Investible Portfolio (DIFCOV1) 
Table 1. Stock Market Liberalization Dates

\begin{tabular}{lc}
\hline \multicolumn{1}{c}{ Country } & $\begin{array}{c}\text { Date of Stock Market } \\
\text { Liberalization }\end{array}$ \\
\hline Argentina & September 1989 \\
Brazil & May 1991 \\
Chile & October 1989 \\
Colombia & December 1991 \\
India & November 1992 \\
Korea & January 1992 \\
Mexico & May 1989 \\
Pakistan & February 1991 \\
Taiwan & January 1991 \\
Turkey & August 1989 \\
Venezuela & January 1990 \\
\hline $\begin{array}{l}\text { Note: Each date corresponds to the earliest stock } \\
\text { market liberalization that occurs after } 12 / 88, \text { which is }\end{array}$
\end{tabular}


Table 2. Comparison of Mean and Median Stock Price Responses to Liberalization for Investible and Non-Investible Firms

\begin{tabular}{|c|c|c|c|c|c|c|c|c|c|}
\hline & \multicolumn{4}{|c|}{$\begin{array}{c}\text { Panel A } \\
\text { Investible } \\
\text { Firms } \\
\end{array}$} & \multicolumn{4}{|c|}{$\begin{array}{c}\text { Panel B } \\
\text { Non-Investible } \\
\text { Firms }\end{array}$} & \multirow{2}{*}{$\begin{array}{c}\text { T-test of } \\
\text { difference } \\
\text { in means } \\
\text { Investible } \\
\text { vs. } \\
\text { Non- } \\
\text { Investible }\end{array}$} \\
\hline & $\begin{array}{l}\text { Number } \\
\text { Firms }\end{array}$ & $\begin{array}{l}\text { Mean Lib } \\
\text { Return }\end{array}$ & $\begin{array}{l}\text { Median } \\
\text { Lib } \\
\text { Return }\end{array}$ & $\begin{array}{l}\text { Number } \\
\text { Negative }\end{array}$ & $\begin{array}{c}\text { Number } \\
\text { Firms }\end{array}$ & $\begin{array}{c}\text { Mean Lib } \\
\text { Return }\end{array}$ & $\begin{array}{l}\text { Median } \\
\text { Lib } \\
\text { Return }\end{array}$ & $\begin{array}{l}\text { Number } \\
\text { Negative }\end{array}$ & \\
\hline $\begin{array}{l}\text { Entire } \\
\text { Sample }\end{array}$ & 248 & 0.151 & 0.121 & $\begin{array}{l}43 \\
(0.00)\end{array}$ & 181 & 0.099 & 0.086 & $\begin{array}{l}83 \\
(0.149)\end{array}$ & Yes* \\
\hline Argentina & 14 & $\begin{array}{c}0.639 \\
(8.466)\end{array}$ & 0.609 & $\begin{array}{l}0 \\
(0.5)\end{array}$ & 10 & $\begin{array}{r}0.391 \\
(5.07)\end{array}$ & 0.302 & $\begin{array}{l}0 \\
(0.000)\end{array}$ & Yes** \\
\hline Brazil & 21 & $\begin{array}{c}-0.052 \\
(-1.029)\end{array}$ & -0.048 & $\begin{array}{l}10 \\
(0.00)\end{array}$ & 23 & $\begin{array}{l}-0.198 \\
(-3.802)\end{array}$ & -0.048 & $\begin{array}{l}11 \\
(0.5)\end{array}$ & Yes* \\
\hline Chile & 9 & $\begin{array}{c}0.048 \\
(1.20)\end{array}$ & 0.071 & $\begin{array}{l}4 \\
(0.5)\end{array}$ & 17 & $\begin{array}{c}0.141 \\
(5.023)\end{array}$ & 0.177 & $\begin{array}{l}8 \\
(0.5)\end{array}$ & Yes** \\
\hline Colombia & 5 & $\begin{array}{c}0.354 \\
(4.223)\end{array}$ & 0.419 & $\begin{array}{l}2 \\
(0.5)\end{array}$ & 15 & $\begin{array}{c}0.287 \\
(6.312)\end{array}$ & 0.310 & $\begin{array}{l}7 \\
(0.5)\end{array}$ & No \\
\hline India & 39 & $\begin{array}{c}0.208 \\
(4.663)\end{array}$ & 0.172 & $\begin{array}{l}7 \\
(0.00)\end{array}$ & 23 & $\begin{array}{c}-0.024 \\
(-0.435)\end{array}$ & -0.054 & $\begin{array}{l}17 \\
(0.994)\end{array}$ & Yes*** \\
\hline Korea & 66 & $\begin{array}{r}0.551 \\
(11.37)\end{array}$ & 0.584 & $\begin{array}{l}7 \\
(0.00)\end{array}$ & 6 & $\begin{array}{c}0.069 \\
(0.406)\end{array}$ & -0.047 & $\begin{array}{l}3 \\
(0.656)\end{array}$ & Yes*** \\
\hline Mexico & 5 & $\begin{array}{c}0.288 \\
(5.48)\end{array}$ & 0.319 & $\begin{array}{l}2 \\
(0.5)\end{array}$ & 36 & $\begin{array}{c}0.247 \\
(8.813)\end{array}$ & 0.223 & $\begin{array}{l}12 \\
(0.033)\end{array}$ & No \\
\hline Pakistan & 5 & $\begin{array}{c}-0.239 \\
(-2.154)\end{array}$ & -0.136 & $\begin{array}{l}1 \\
(0.188)\end{array}$ & 38 & $\begin{array}{c}-.01 \\
(-0.478)\end{array}$ & 0.004 & $\begin{array}{l}19 \\
(0.564)\end{array}$ & Yes*** \\
\hline Taiwan & 69 & $\begin{array}{c}0.329 \\
(11.899)\end{array}$ & 0.332 & $\begin{array}{l}4 \\
(0.00)\end{array}$ & 0 & N/A & $\mathrm{N} / \mathrm{A}$ & $\mathrm{N} / \mathrm{A}$ & N/A \\
\hline Turkey & 10 & $\begin{array}{c}0.654 \\
(8.532)\end{array}$ & 0.577 & $\begin{array}{l}4 \\
(0.00)\end{array}$ & 5 & $\begin{array}{r}0.509 \\
(10.01)\end{array}$ & 0.577 & $\begin{array}{l}2 \\
(0.5)\end{array}$ & Yes*** \\
\hline Venezuela & 5 & $\begin{array}{c}0.446 \\
(4.223)\end{array}$ & 0.451 & $\begin{array}{l}2 \\
(0.5)\end{array}$ & 8 & $\begin{array}{c}0.478 \\
(4.723) \\
\end{array}$ & 0.451 & $\begin{array}{l}4 \\
(0.637)\end{array}$ & No \\
\hline
\end{tabular}

Notes: The mean liberalization return is the average stock price change in Month [0]. T-statistics are given in parentheses. The median liberalization return is the median stock price change in Month [0]. Column 4 in Panels A and B reports the number of firms that experienced liberalization month returns that were below their own historical median return. P-values for sign tests for the median returns are shown in parentheses. The final column reports results from a T-test of the difference in

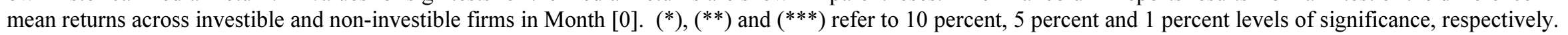


Table 3 Comparison of Investible and Non-Investible Firms Before Stock Market Liberalization

\begin{tabular}{|c|c|c|c|c|c|c|c|c|c|c|c|}
\hline & \multicolumn{5}{|c|}{ Investible Firms } & \multicolumn{5}{|c|}{ Non-InvestibleFirms } & \multirow{2}{*}{$\begin{array}{l}\text { Significant } \\
\text { Difference? } \\
\text { (t-test Mean) }\end{array}$} \\
\hline & Mean & Median & Min & Max & St. Dev & Mean & Median & Min & Max & St. Dev & \\
\hline Size & 0.015 & 0.006 & 0.0004 & 0.129 & 0.023 & 0.014 & 0.006 & 0.0002 & 0.135 & 0.019 & No \\
\hline Liquidity & 2.66 & 0.43 & 0.003 & 26.9 & 5.11 & 0.249 & 0.083 & 0 & 2.35 & 0.364 & Yes*** \\
\hline $\begin{array}{l}\text { Earnings } \\
\text { Growth }\end{array}$ & 0.18 & 0.08 & -4.20 & 5.80 & 1.02 & 0.10 & 0.05 & -4.01 & 6.50 & 1.11 & Yes** \\
\hline $\begin{array}{l}\text { Market } \\
\text { to Book }\end{array}$ & 3.30 & 1.72 & -1.27 & 78.0 & 6.12 & 1.48 & 1.03 & -3.30 & 7.75 & 1.50 & Yes*** \\
\hline DIFCOV & 0.018 & 0.01 & -0.001 & 0.123 & 0.017 & 0.01 & 0.004 & -0.038 & 0.069 & 0.016 & Yes $^{* * *}$ \\
\hline
\end{tabular}


Table 4. Average Annual Growth Rate of Real Earnings Per Share Around Liberalization

\begin{tabular}{|c|c|c|c|}
\hline & Investible & Non-Investible & $\begin{array}{c}\text { Significant } \\
\text { difference? } \\
\text { (F-Test) }\end{array}$ \\
\hline$[+1]$ & $\begin{array}{l}-0.217 * * * \\
(0.066)\end{array}$ & $\begin{array}{l}-0.393 * * * \\
(0.090)\end{array}$ & Yes** \\
\hline$[+2]$ & $\begin{array}{l}-0.230 * * * \\
(0.068)\end{array}$ & $\begin{array}{l}-0.113 \\
(0.099)\end{array}$ & No \\
\hline$[+3]$ & $\begin{array}{l}-0.106 \\
(0.068)\end{array}$ & $\begin{array}{l}-0.014 \\
(0.101)\end{array}$ & No \\
\hline Constant & $\begin{array}{c}0.027 \\
(0.024) \\
\end{array}$ & $\begin{array}{l}-0.036 \\
(0.035)\end{array}$ & \\
\hline \multicolumn{4}{|c|}{$\begin{array}{l}\text { Notes: }[+1],[+2] \text { and }[+3] \text { report growth rates of real earnings in the first, second anc } \\
\text { third year following the liberalization. Country-fixed effects are included in al } \\
\text { regressions but are not reported. The F-test reports results about the statistica } \\
\text { significance of the difference in the mean growth rates for investible and non } \\
\text { investible firms. }(*),(* *) \text { and }(* * *) \text { refer to } 10 \text { percent, } 5 \text { percent and } 1 \text { percen } \\
\text { levels of significance, repectively. }\end{array}$} \\
\hline
\end{tabular}


Table 5. Does Diversification Drive Stock Price Revaluations?

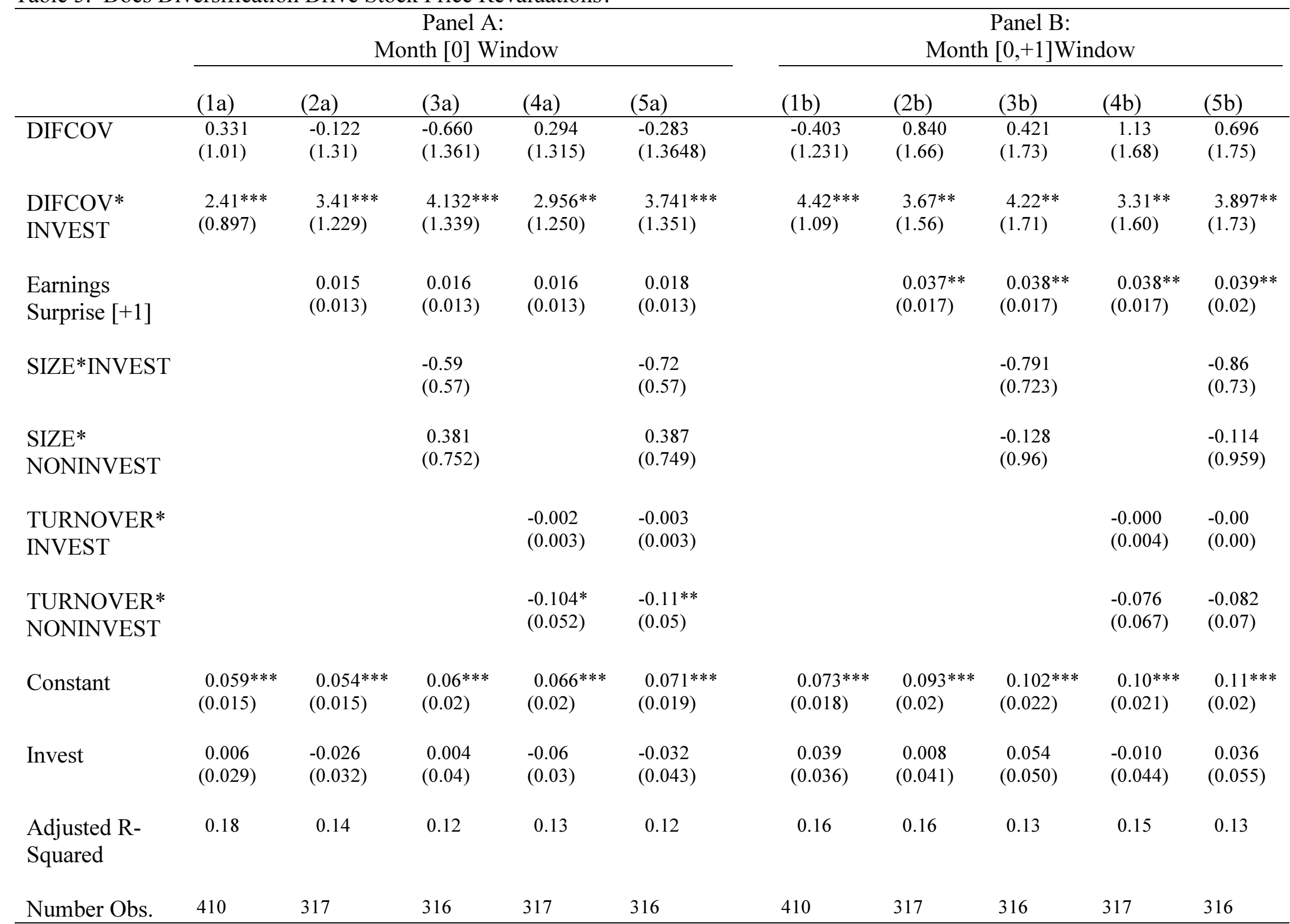

Notes for Table 5: The LHS side variable in Panel A is the abnormal return in the liberalization month. The LHS variable in Panel B is the cumulative abnormal return in the liberalization month plus one month. The symbol DIFCOV is the difference between the historical covariance of firm i's stock return with the local market and its covariance with the Morgan Stanley Capital Market Index (MSCI) world stock market index. Country-fixed effects are included in all regressions but are not reported. INVEST is a dummy variable that takes on a value of one for investible firms and zero for non-investible firms. SIZE is defined as the ratio of that firm's market capitalization to the total domestic market capitalization as of one year prior to the liberalization date. TURNOVER is defined as the sum of the dollar value of all shares traded over a 12-month period before the liberalization $(t=-24$ to $t=-12)$ divided by that firm's total market capitalization. Earnings Surprise $[+1]$ is the deviation of the growth rate of earnings from its pre-liberalization mean in year $[+1]$ following the liberalization. $(*),(* *)$ and $(* * *)$ indicate significance at the 10 percent, 5 percent and 1 percent, respectively. Robust standard errors adjusted for clustering within parentheses. 